\title{
The Assessment of Medical Students' Chronotypes
}

\author{
José Reinaldo Maximo Gomes ${ }^{1}$, Fátima Karine Ferreira Santosㄴ, Isaac Filipe Melo de Freitas, \\ Ilma Ferreira de Oliveira1, Hete Aguida dos Santos' ${ }^{1}$, José Cláudio da Silva1, Janise Dal Pai², \\ Lysien Ivania Zambrano ${ }^{3}$, Euclides Mauricio Trindade Filho ${ }^{*}$, Milton Vieira Costa ${ }^{1}$ \\ ${ }^{1}$ Laboratório de Neurociência e comportamento, Universidade Estadual de Ciências da Saúde de Alagoas—UNCISAL, Maceió, \\ Brasil \\ ${ }^{2}$ Universidade Nove de Julho (UNINOVE), São Paulo, Brasil \\ ${ }^{3}$ Facultad de Ciencias Medicas, Universidad Nacional Autónoma de Honduras, Tegucigalpa, Honduras \\ Email: *emtfilho@gmail.com
}

How to cite this paper: Gomes, J.R.M., Santos, F.K.F., de Freitas, I.F.M., de Oliveira, I.F., dos Santos, H.A., da Silva, J.C., Dal Pai, J., Zambrano, L.I., Filho, E.M.T. and Costa, M.V. (2017) The Assessment of Medical Students' Chronotypes. World Journal of Neuroscience, 7, 275-281.

https://doi.org/10.4236/wjns.2017.73023

Received: May 25, 2017

Accepted: July 15, 2017

Published: July 18, 2017

Copyright $\odot 2017$ by authors and Scientific Research Publishing Inc. This work is licensed under the Creative Commons Attribution International License (CC BY 4.0).

http://creativecommons.org/licenses/by/4.0/

\begin{abstract}
Objective: This study aimed to investigate the circadian typology of medical students at public universities from one of the northeastern states in Brazil, active in the morning and afternoon shifts, checking the compatibility between their study time, productivity, income and chronotype. Methods: To obtain the results, the assessment of the chronotype in 342 medical students of both sexes was considered. Each participant was submitted to the questionnaire developed by Horne and Ostberg, adapted by Cardinali, Colomberk and Rey. It's composed of 9 questions, providing the general ranking of each individual. Based upon scored, the chronotypes were classified. Results: The sample was composed of $49.12 \%$ (168) male and $50.87 \%$ (174) female subjects, a similar gender distribution of enrolled students during data collection time. By applying the questionnaire, the prevalent rating among the medical students as moderately morning (29.82\%) and intermediate (43.85\%) has been relevant. The academic performance assessment in two morning-intermediate groups (8.16) had no significant distance from others considered afternoon active (8.20). Conclusion: The health sciences student, especially Medicine, faces constant adaptation of scheduling, in the attempt of fulfilling the requirements throughout the course, causing chronogram desynchronization effects and forced readaptation to each different school semester.
\end{abstract}

\section{Keywords}

Circadian Rhythm, Chronobiology Disorders, Delivery of Health Care, Medicine, Sleep Disorders

\section{Introduction}

The preference for morning-afternoon shifts is the individual difference that ex- 
plains the variation in the rhythmic expression of biological and behavioral patterns [1] [2]. It allows relate the adaptability and the daily performance when changes are required in sleeping habits, which may affect or disrupt this important functional status [1].

This occurs because light stimulates specific cells located in the retina (melatonin as photoreceptor) sending neural projections via retinohypothalamic tract directly to the suprachiasmatic nucleus (structure located in the hypothalamus). Due to the control of biological clock, light has been currently considered as the main synchronizer agent [3] in organism.

A proper functioning of this synchronization system allows an alignment between environmental cycles. It provides an anticipation capacity, which allows the organism obtain resources to be prepared for events and activities indispensable for life [4]. Though related to environmental cycle, the rhythms are not only variations in medium so, without temporal fluctuations it continues expressing for days, months or years, depending on species [5]. This study aims correlate chronobiological rhythms with academic performance in medical students, in order to serve as a guide to allocate them according to the time of greater disposition to carry out daily activities.

\section{Methods}

This is an observational study with cross-sectional approach. Participated in study medical studentd in Maceió, capital of Alagoas, a state in the Northeast region of Brazil. Maceió is a coastal city, with approximately 932,000 inhabitants, is located at $9^{\circ} 39^{\prime} 59^{\prime \prime}$. The study was conducted from August 2015 to August 2016.

Participants were recruited following the inclusion and exclusion criteria, they were aware of participation and signed an application of Free and Informed Consent.

Each of 342 students has been submitted to the questionnaire proposed by Horne and Ostberg [6], adapted by Cardinali et al. [7]. It is composed of 9 questions where the score assigned to each response followed the table proposed by Cardinali et al. [7] (Table 1). Based on the obtained result, chronotypes has been classified.

The academic performance has been analyzed using income coefficients from each student, provided by the Academic Division.

The study has been conducted following the ethical standards to chronobiological researches in humans, following the Declaration of Helsinki's guidelines of the World Medical Association [8], and approved by the Research Ethics Committee from Health Sciences State University of Alagoas-UNCISAL, as well as the approval of Faculty of Medicine Council from Federal University of Alagoas-UFAL.

\section{Results}

The study included 342 students, consisting $97.2 \%$ of 352 questionnaires, which 
Table 1. Score board with the answer selection from the chronotype evaluation questionnaire, proposed by Horne \& Ostenberg, adapted by Cardinali, Colomberk \& Rey.

\begin{tabular}{cccccc}
\hline \multirow{2}{*}{ QUESTION ORDERING } & \multicolumn{5}{c}{ OPTIONS } \\
\cline { 2 - 6 } & $\mathrm{A}$ & $\mathrm{B}$ & $\mathrm{C}$ & $\mathrm{D}$ & $\mathrm{E}$ \\
\hline 2 & 1 & 2 & 3 & 4 & 5 \\
3 & 1 & 2 & 3 & 4 & - \\
4 & 1 & 2 & 3 & 4 & 5 \\
5 & 1 & 2 & 3 & 4 & - \\
6 & 1 & 2 & 3 & 4 & - \\
7 & 4 & 3 & 2 & 1 & - \\
8 & 4 & 3 & 2 & 1 & - \\
9 & 1 & 2 & 3 & 4 & - \\
\hline
\end{tabular}

09 to 15 -> Definitely morning; 16 to 20 -> Moderately morning; 21 to 26 -> Intermediate; 27 to 31 -> Moderately.

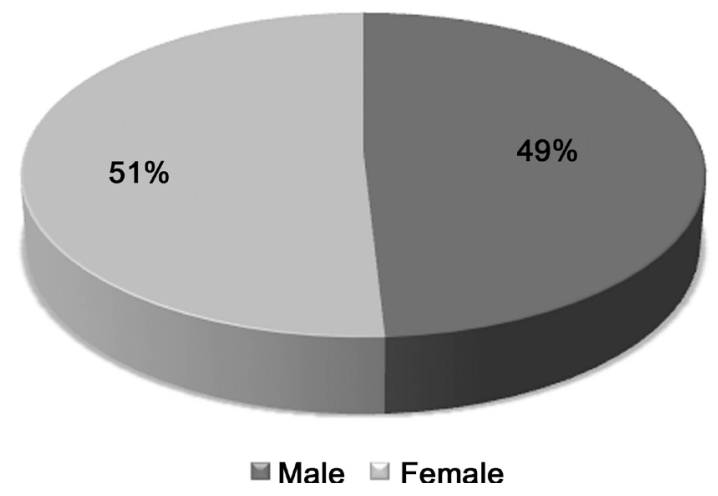

Figure 1. Disposition of individuals according to gender.

has been assigned and returned. Losses occurred due to incomplete and inconsistent filling. From the total amount of sample, $49.12 \%$ (168) were male and $50.87 \%$ (174) were female (Figure 1).

The ages of the students ranged from 18 to 61 years $(24.11 \pm 5.77$; median $=$ 24). Was observed a predominance of age in the range of 21 - 24 years (38.65\%).

Chronobiological questionnaire showed that 8 (2.3\%) were definitely morning (DM), 102 (29.82\%) were moderately morning (MM), 150 (43.85\%) were intermediates (I), 66 (19.29\%) were moderately afternoon (MA) and 16 (4.67\%) was definitely afternoon (DA) (Table 2). A marked difference has been found between genders, confirming a higher proportion of men preferring the afternoon shift $(27.38 \%)$ compared to women (20.69\%), with morning preference (Figure 2).

By analyzing the predominance of points according to their grouping, the frequency of scores displays a regular distribution (Figure 3 ). There were a variation between 10 and 37 points $(13.03 \pm 11.29)$, with a predominance of those who scored 20 points, representing $39.20 \%$ of the "moderately morning" rated. 
Table 2. Chronotype division of interviewed participants.

\begin{tabular}{ccc}
\hline Chronobiological Type & N\# & $\%$ \\
\hline Definitely morning & 8 & 2.3 \\
Moderately morning & 102 & 29.82 \\
Intermediate & 150 & 43.85 \\
Moderately afternoon & 66 & 19.29 \\
Definitely afternoon & 16 & 4.67 \\
Total & 342 & 100 \\
\hline
\end{tabular}

Caption: Frequency of chronotypes displayed by 342 medical students from public universities in the State of Alagoas, analyzed according to the questionnaire proposed by Horne \& Ostberg, adapted by Cardinali, Colomberk \& Rey.

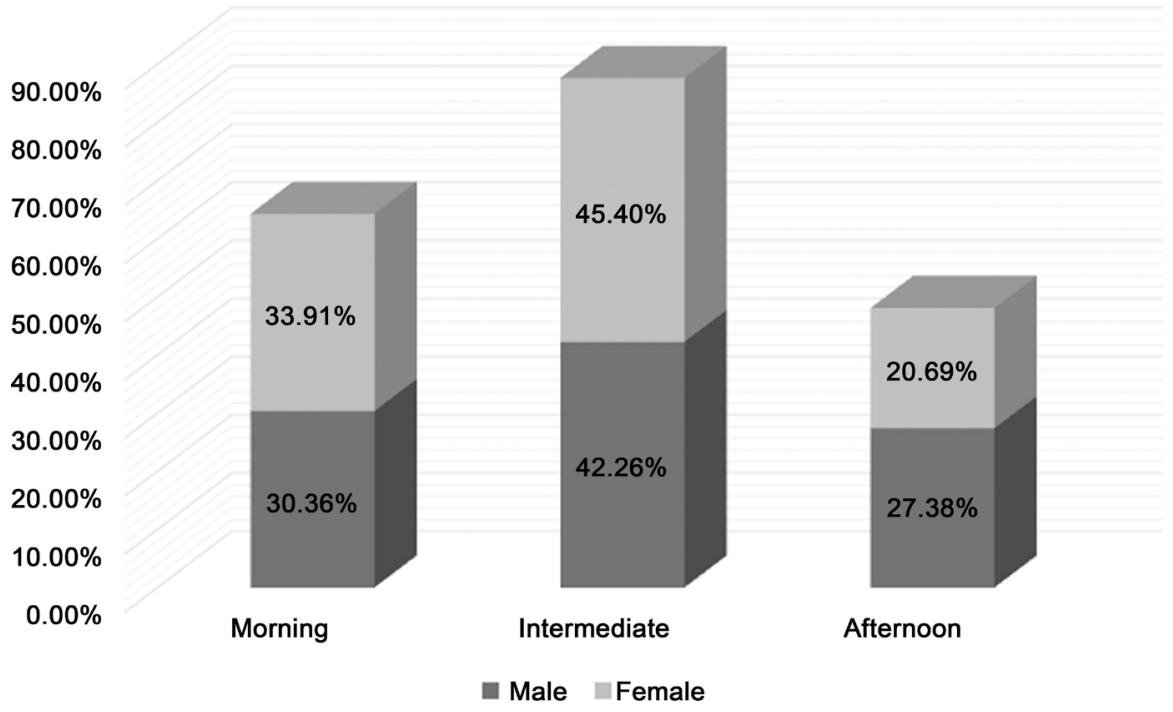

Caption: Gender distribution according to greater chronobiological productivity.

Figure 2. Gender distribution according to the chronotypes.

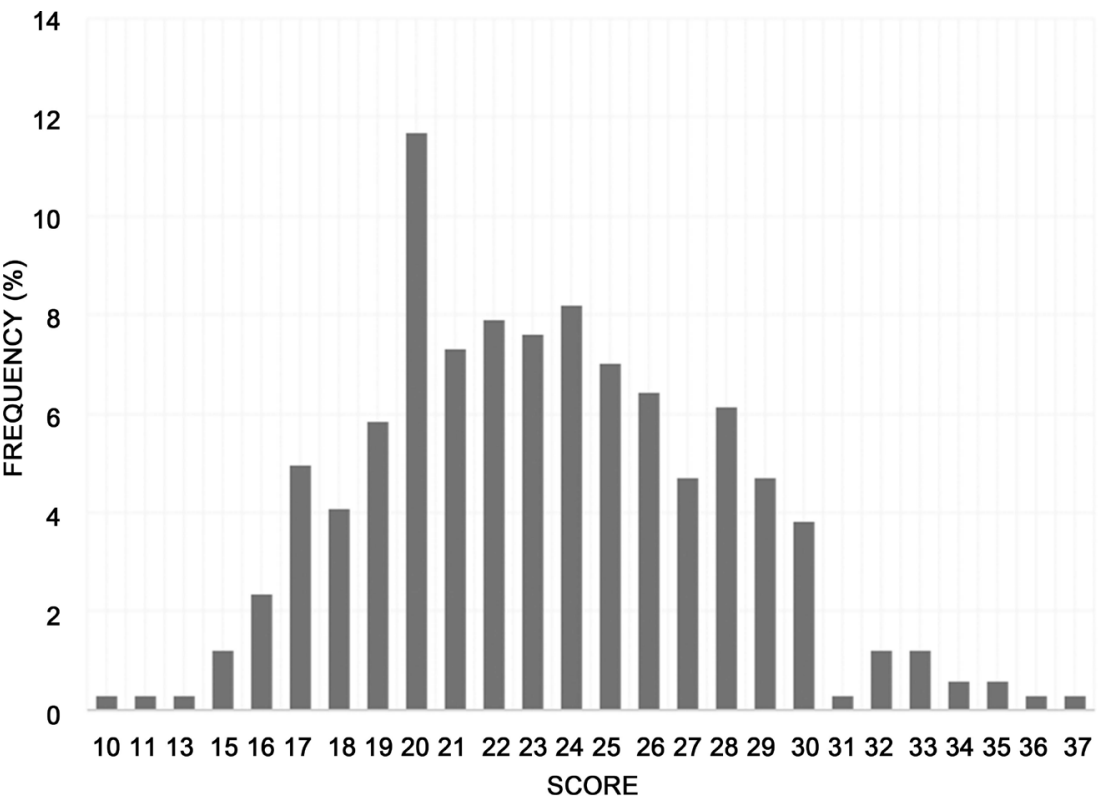

Caption: Frequency of scores in chronotype questionnaire from the total sample of participants.

Figure 3. Score distribution from the chronotype questionnaire. 
Analysis of academic coefficients from all interviewed students revealed no correlation between academic developments with period of greatest productivity. Students classified as morning, intermediate and afternoon have obtained an academic coefficient average of $8.16,8.23$ and 8.20 , respectively.

\section{Discussion}

Age and gender from participants were no considerably different, probably due to a homogeneity presented in both male and female samples, and a predominant consistency of young individuals. A study by Monk and Kupfer [9] reports individuals tend to advance the phase of their biological rhythms, prone to becoming most-morning active as the ongoing of the age.

Similarly, differences between preferences in both genders are observed in the results obtained by Mongrain et al. [10]. They have studied gender differences in young-adult students between 17 and 35 years old and. have showed higher scores reflecting most morning activities in women than men.

Classifying students as intermediaries' chronotype means that this group has greater flexibility compared to other groups when schedules are changed. These students are able to awake earlier or later, and fulfill daily academic activities with a satisfactory alert level in every moment. However, performing activities outside to own chronotype period may result in learning difficulties, due to cognitive troubles like, memory, visual perception, mental skill or muscle strength [11].

Higher-Education students, especially Medicine, are often susceptible to schedule shifting, because there is a greater effort and time disposition required by the course. This may compromise a proper functioning of the body and affect the performance of such operations. Forced to change or switch the period that show higher productivity they may compromise the academic performance. Alam et al. [1] have showed that students classified as morning-active do not adapt well to nocturnal tasks, due to unsatisfactory sleeping length of time, because they remain dissociated caused by the strict behavior when resting. Afternoon-active students may suffer more sleep deprivation (shortening), caused by the setting time of school appointments or work, establishing a conflict: a preference for sleeping until late but interrupted by an alarm clock.

When analyzing the income coefficient from individuals, according to chronotype in academic activity shifts, the afternoon-active shows a better performance $($ mean $=8.20)$ compared to morning and intermediate groups (mean = 8.16), however, there is no significant difference. In contrast, Ferreira and Martin [12], evaluating the distribution of individuals on work according to chronotype, have demonstrated that, morning individuals as better allocated. Campos et al. [13] indicate that both matutine and vespertine people generally have higher performance on tasks when matching to their own chronotypes.

In this context, courses in health sciences, especially Medicine, is constantly adapting the schedule, attempting to satisfy needs and exigencies throughout graduation. This, increase demand along the course and so, desynchronization 
with chronotype needing new adaptations by every semester. Hence, promoting biological deregulation and changes lead to compromise the process of learning in the academic life. As displayed by Parks et al. [14], health science students need to be aware of difference in their vulnerability to errors, decisions and shortcomings in producing at night, especially when fatigued. Equally important the instruction on circadian rhythms in performance and cognitive abilities, as well as recognizing the drudgery effects, resulted by increased workload.

Due to increasing acknowledge of social significance in Chronobiology, an organization and a chronobiological planning for students' daily activities is required, aiming both a better academic performance and therefore, elevated course fulfilment. The adjustment between social and biological time, will increase the welfare of students, triggered by respecting their physiology.

\section{Acknowledgements}

To the support from Institutional Program for Scientific Initiation Scholarships PIBIC/ CNPq 2015-2016 for this study. And the relevant support from the Faculty of Medicine's Council in the Federal University of Alagoas, for the collection of data.

\section{References}

[1] Alam, M.F., Tomasi, E., Lima, M.S., Areas, R. and Menna-Barreto, L. (2008) Caracterização e distribuição de cronotipos no sul do Brasil: diferenças de gênero e estação de nascimento. Jornal Brasileiro de Psiquiatria, 57, 83-90. https://doi.org/10.1590/S0047-20852008000200001

[2] Garaulet, M. and Gómez-Abellán, P. (2013) Chronobiology and Obesity. Nutrícion Hospitalaria, 28, 114-120. https://doi.org/10.1007/978-1-4614-5082-5

[3] Squarcini, C.F.R. and Esteves, A.M. (2013) Cronobiologia e inclusão educacional de pessoas cegas: do biológico ao social. Revista Brasileira de Educação Especial, 19, 513-530. https://doi.org/10.1590/S1413-65382013000400004

[4] Pereira, D.S., Tufik, S. and Pedrazzoli, M. (2009) Moléculas que marcam o tempo: implicações para os fenótipos circadianos. Revista Brasileira de Psiquiatria, 31, 6371. https://doi.org/10.1590/S1516-44462009000100015

[5] Almondes, K.M. (2006) Tempo na psicologia: contribuição da visão cronobiológica à compreensão biopsicossocial da saúde. Psicologia: Ciência e Profissão, 26, 352359. https://doi.org/10.1590/S1414-98932006000300002

[6] Horne, J.A. and Ostberg, O.A. (1976) Self Assessment Questionnaire to Determine Morningness-Eveningness in Human Circadian Rhythms. International Journal of Chronobiology, 4, 97-110.

[7] Cardinali, D.P., Colomberk, D.A. and Rey, R.A.B. (1992) Relojes y Calendários Biológicos La Sincronia del hombre com el médio ambiente. Fondo de Cultura Econômica, Buenos Aires, 59-87.

[8] Declaração de Helsinque da Associação Médica Mundial (WMA). Princípios éticos para Pesquisa Médica Envolvendo Seres Humanos. Disponível em: http://www.amb.org.br acesso em 21 de julho de 2016.

[9] Monk, T.H. and Kupfer, D.J. (2007) Which Aspects of Morningness-Eveningness Change with Age? Journal of Biological Rhythms, 22, 278-280.

https://doi.org/10.1177/0748730407301054 
[10] Mongrain, V., Paquet, J. and Dumont, M. (2006) Contribution of the Photoperiod at Birth to the Association between Season of Birth and Diurnal Preference. Neuroscience Letters, 406, 113-116. https://doi.org/10.1016/j.neulet.2006.07.002

[11] Alves, P.C., Neves, V.F., Dela Coleta, M.F. and Oliveira, A.F. (2012) Avaliação do bem-estar no trabalho entre profissionais de enfermagem de um hospital universitário. Rev. Latino-Am. Enfermagem, 20, [08 telas].

[12] Ferreira, L.R.C. and Martino, M.M.F. (2009) Stress no cotidiano da equipe de enfermagem e sua correlação com o cronótipo. Estudos de Psicologia (Campinas), 26, 65-72. https://doi.org/10.1590/S0103-166X2009000100007

[13] Campos, T.F., Pinheiro, C.D.G., Diógenes, F.P., Barroso, M.T.M. and Dantas, A.A.T.S.G. (2011) Cronotipo e implicações para sua utilização na fisioterapia em pacientes com acidente vascular encefálico. Fisioterapia e Pesquisa, 18, 258-263. https://doi.org/10.1590/S1809-29502011000300010

[14] Parks, D.K., Yetman, R.J., McNeese, M.C., Burau, K. and Smolensky, M.H. (2000) Day-Night Pattern in Accidental Exposures to Blood-Borne Pathogens among Medical Students and Residents. Journal Chronobiology International, 17, 61-70. https://doi.org/10.1081/CBI-100101032

\section{Scientific Research Publishing}

\section{Submit or recommend next manuscript to SCIRP and we will provide best} service for you:

Accepting pre-submission inquiries through Email, Facebook, LinkedIn, Twitter, etc. A wide selection of journals (inclusive of 9 subjects, more than 200 journals) Providing 24-hour high-quality service User-friendly online submission system Fair and swift peer-review system Efficient typesetting and proofreading procedure Display of the result of downloads and visits, as well as the number of cited articles Maximum dissemination of your research work

Submit your manuscript at: http://papersubmission.scirp.org/ Or contact wjns@scirp.org 